\title{
ACTIN CYTOSKELETON STRUCTURE AND ITS LOCALIZATION IN Gongronella butleri, Mucor javanicus AND Absidla cylindrospora (Mucorales-Zygomycetes)
}

\section{Estructura y su localización del citoesqueleto de actina en Gongronella butleri, Mucor javanicus y Absidia cylindrospora (Mucorales - Zygomycetes)}

\author{
Shari'a, Allana E. N. ${ }^{{ }^{*}}$,Nascimento, A.E, ${ }^{1,2}$ Campos-Takaki, G.M. 1,2 \\ 1. Laboratório de Imunopatologia Keizo Asami (LIKA) - Univ. Federai \\ de Pemambuco (UFPE);2. Univ. Católica de Pernambuco. \\ *Corresponding Author: Avenida Beberibe, 2917-Fundao. Recife/PE. Brasil.
}

CEP: 52.130-000/FAX: 081-2164001.

Palabras clave: Zygomycetes, actina, microscopía de fluorescencia

Key Words: Zygomycetes, actin, fluorescent microscopy

\section{SUMMARY}

The distribution and localization of actin in hyphae of zygomycetous fungi were examined by FITCphalloidin staining of paraformaldehyde fixed cells by using fluorescent light microscopy. The cytochemistry study using Absidia cylindrospora, Gongronella butleri and Mucor javanicus revealed that the distribution and localization of actin in mycelia were under different patterns and arrangements such as filaments, patches, peripheral plaques or spots and granules with prevalence of patches. Actin patches ocurred throughout the peripheral cytoplasm. Actin fibers oriented parallel to the long axis were observed and associations between patches and fibers were visualized. A diffuse amorphous cytoplasm staining was visualized in central region of cytoplasm. Actin staining in hyphae tips was observed only in Mucor javanicus. This differentiation in actin arrangement could be related to the differences in the expansion zones of the cell wall of fungal species studied.

\section{INTRODUCTION}

Zygomycetes are of great interest for the industry and economy due to its involvement in the process of biodegradation, biodeterioration and in the secretion of secondary metabolites (Dube, 1978; Tombs \& Blake, 1982; Endo et al., 1985; Trudel \& Asselin, 1990; Certik et al., 1997).

In human medicine zygomycetes species are considered opportunistic pathogens to immu!no-

\section{RESUMEN}

Mediante estudios de microscopia óptica de fluorescencia se describe y caracteriza la estructura, distribución y localización de la actina, en tres especies de hongos de la clase Zygomycetes: Absidia cylindrospora, Gongronella butleri y Mucor javanicus. La estructura de la actina fué analizada utilizándose el marcador FITCPhalloidina, especifico para actina, en muestras fijadas con formaldehido. En los resultados se observan diferencias en la estructura, distribución y localización de esta proteina en las especies analizadas. Filamentos, aglomerados, placas o aglomerados periféricos y gránulos, fueron las formas más comunes encontradas en los hongos, con prevalencia de los aglomerados observados en todo lo citoplasma de las hifas. La tinción de actina en los ápices de las hifas, solo se observó en Mucor javanicus, esta diferencia en la estructura de la actina podria estar asociada a zonas de expansión de la pared celular de los hongos.

compromised host. However, many zy'gomicosis cases are described in apparently healthy individuals. Clinical manifestations of zygom,icosis including rhinocerebral, gastric, pulmonar, sino-orbital, cutaneous and systemic (Bittencourt et al., 1980; Lehrer et al., 1980; Levy et al., 1986; Espinel-Ingroff et al., 1987; Walsh et al., 1994; Attapattu, 1995; Kimura et al., 1995; Weitzman et al., 1995; West et al., 1995; Schipper et al., 1996; Mítchell et al., 1996).

It is now well established that most animal cells con- 
tain ordered arrays of three major fiber systems: microtubules, microfilaments and intermediate filaments, which correspond to the cell cytoskeleton. Their organization in different cell types has been extensively studied. These systems are involved in many diverse functions including developement and control of cell morphology and polarity, adhesion, membrane stability, organelle movements, cellular division and growth (Schliwa \& Blerkom, 1981; Hitt \& Luna, 1994).

Previous experimental data suggest that the action of cytoskeleton may be fundamentally involved in hyphal growth, morphogenesis and migration of cytoplasmic elements of fungal cell (Howard \& Raist, 1980; Hoch \& Staples, 1.983; Anderson \& Soll, 1986; Heath, 1987, 1988, 1990; Butt \& Heath, 1988; Salo et al., 1989; Bartinicki-Garcia et al., 1990; Jackson \& Heath, 1990; Temperli et al., 1990; Roberson, 1992).

Although the presence of actin and tubulin in fungal hyphae is not questioned, its spatial organization in most fungal species remain uncertain. Indeed, in spite of zygonycetes importance, studies on their basic biology are scarse (Butt \& Heath, 1988), mainly those concerning to cytoskeleton elements structure, distribution and functions. It is therefore of considerable interest to investigate the cytoskeleton in these organisms.

It was the aim of this investigation to identify and describe the distribution, structure and localization of actin cytoskeleton in hyphal cells of Absidia cylindrospora, Gongronella butleri and Mucor javanicus as detected by fluorescence optical microscopy by using phalloidin coupled to fluorescein isothyiocianate. Phalloidin is a fungal toxin obtained from Amanita phalloides (Basidiomycetes), which has a specific affinity for actin.

\section{MATERIALS AND METHODS}

\section{Organisms and Cultures}

Absidia cylindrospora 3351 Hagem, Gongronella butleri 2151 (Lender)Peyronel \& Dal Vasco and Mucorjavanicus 1989 Whemer. The isolates were obtained from Departamento de Micologia da Universidade Federal de Pernambuco, Brasil. Stock cultures were manteined in PDA (Potato Dext. Agar) medium, wherein the organisms exhibited the maximum growth, and were incubated at $26^{\circ} \mathrm{C}$.

The myceka of Absidia cylindrospora 3351, Gongronella butleri 2151 and Mucor javanicus 1989 were grown in liquid synthstic medium for mucoralean (SMM), described by Hesseltire \& Anderson (1957), modified by Campos-Takaki (1984). The organisms were grown during 3 days at $26^{\circ} \mathrm{C}$ in a recipracal shaker $(200 \mathrm{~Hz})$.

\section{Fluorescence Optical Microscopy}

Collected samples were washed in phosphatebuffered saline (PBS) at $\mathrm{pH} 7,2$ and fixed by immersion in $4 \%$ formaldehyde, prepared from paraformaldehyde granules, in PBS at $\mathrm{pH} 7,2$ for 30 minutes at room temperature. Samples were rinsed in three 10 minutes changes each being PBS at pH 7,2. At this point, samples were attached to polyL-lysine-coated slides without air drying.

Fixed hyphal cells were incubated for 20 minutes in $0,1 \%$ triton X-100 in PBS to partially solubilized plasma membrane. After a brief wash in PBS, samples were incubated for 10 minutes in PBS-BSA $(0,1 \%(\mathrm{p} / \mathrm{v})$ bovine serum albumin).

Samples were incubated in fluorescein isothiocyanate (FITC)-conjugated phalloidin diluted 1:100 in PBS, over-night at $4^{\circ} \mathrm{C}$. After rinse in PBS, samples were mounted in $90 \%$ glycerol: $10 \%$ carbonate bicarbonate buffer $(0,1 \mathrm{M}$, $\mathrm{pH} 9,2$ ).

Observations and photomicrographs were made on Olympus BH2 light microscopy equipped for epifluorescence viewing. The excitation, reflector, and barrier filters used for FITC were 400-490, 510, and $520 \mathrm{~nm}$ respectively. Photomicrographs were taken with Kodak Tmax film exposed at $400 \mathrm{ASA}$.

\section{RESULTS}

Light microscopic fluorescence localization of actin in formaldehyde-fixed hyphal cells of Absidia cylindrospora, Gongronella butleri and Mucor javanicus resulted in highly reproducible fluorescent images.

The sites of FITC-phalloidin labeling appeared as brightly fluorescent individual plaques or spots, coarse longitudinal fibers, patohes arid diffuse and amorphous cytoplasrnic staining in the organisms studied.

The experimental fluorescence control not incubated with FITC-phalloidin, showed no fluorescence at all (Figure 1).

The cytoplasmic region of hyphal cells of Absidia cylindrospora had a diffuse, amorphous fluorescent staining. Actin patches and filaments in cytoplasmic region are also identified. The septum region exhibited a fluorescent band (Figure 2).

Coarse actin fibers could be seen in hyphae periphery. Intense bright fluorescent patches in cytoplasmic region were also observed in Absidia cylindrospora (Figure 3 ).

In Gongronella butleri transverse cross-bands with fluorescence staining were observed in septum region and hyphae branching. Actin coarse fibers and actin filaments were also seen in hyphae cytoplasm (Figure 4).

Intense actin fluorescence staining in the form of 
patches, plaques and granules was visualized in Gongronella butleri. An amorphous diffuse actin staining was observed in central cytoplasmic region (Figure 5).

At the periphery of the hyphac. coarse actin fibers and filaments in close association with peripheral patches could be observed (Figure 6).

Actin fluorescence staining diffuse amorphous was observed through hyphae cytoplasm of Mucor javanicus. The organism presented actin in the form of thin filaments (Figure 7).

Bright fluorescent spots in hyphae periphery, an amorphous fluorescent staining and thin filaments staining in branching region were also observed in Mucor javanicus. Actin filaments and patches associations were also seen in a branching region of the hyphae (Figure 8).

Actin fibers and filamentous arrangement with high fluorescent staining oriented parallel to the longitudinal axis of cell wall were observed in all species (Figures 2-8).

In hyphae examined the most obvious form of actin labeling was visualized as individual patches.

\section{DISCUSSION}

Fluorescence microscopy by using FITC-phalloidin had provided a more complete view of the actin cyloskeleton in many cell types. Until 1983 the actin was not demonstrated in filamentous fungi through light microscopy. Since then many researchers have dedicated their attention to characterize the actin cytoskeleton in fungal cell and the results showed a great variability related to structure and distribution in the species studied (Hoch \& Staples. 1983).

Actin in mycelial fungi has been demostrated mostly in situ by immunological and cytochemical methods through electron and optical microscopy (Heath. 1987; Hoch \& Staples, 1983: Runenberg \& Raudaskoski. 1986)

The light microscopic results presented in this study reveal that actin is arranged in different forms in all species studied: 1. individual plaq̣ues, patches and spots: 2. coarse fibers; 3 . thin filaments arid 4 . amorphous cytoplasmic actin.

These general observations were similar to previous light microscopic investigations of hyphae cells using fluorescent-labeled phallotoxin. Howerer. actin bindingproteins may influence the properties of actin arrangement and the observation of different patterns of actin distribution, localization and forms could be related to this protein activity (Heath, 1987).

The actin distribution and structure in hyphal cells may vary among different fungi classes. In Oomycete Saprolegnia ferax (Heath. 1987: Heath. 1988: Jackson \& Heath. 1990) and during uredospores germination of the basidiomycete Uromyces phaseoli (Hoch \& Staples. 1983). long filaments were homogeneously distributed.

On the other hand, the hyphae of various basidiomycetous fungi actin was mostly preserved in the form of granules (Salo et al. 1989).

Temperli et al., (1990) describe structural arrangement of actin such as globular, small granules and with a high fluorescente intensity.

In Neurospora crassa (Ascomycetes) actin staining in apical region was observed as cap arrangement and in subapicai region the actin was in the form of bright spots along the hyphal axis (Barja et al., 1991).

Roberson (1992) related the presence of actin in Sclerotium rolfsii, in this fungi. actin was in the form of fluorescent patches. longitudinal fibers. subapical-cross bands and diffuse, amorphous cytoplasmic actin. In the apical region the actin was observed in the form of individual patches.

Gongronella butleri was the species with the highest fluorescent staining and presented the actin in different arrangements, fibers, patches, filaments. plaques, spots and amorphous forms were observed. A pattern similar to Sclerotium rolfsii. Indeed. the species exhibited coarse associations between actin fibers and patches. Actin staining was observed in regions of septa and branching of the mycelia.

In Mucor javanicus cytoplasmic staining located in hyphal tips as amorphous cap arrangement with high fluorescence was observed. Actin fibers and plaques along the longitudinal axis of the hyphae were observed, which possibly correspond to the zones of wall cxpansion.

Absidia cylindrospora exhibited actin plaques in cytoplasmic region with high fluorescent staining and plaques in regions of branching and septa of the hyphae with weak staining.

The results showed in this work suggest the existence of a great diversity in structure and distribution of actin cyloskeleton in Zygomycetes. The actin cytoskeleton therefore may be assosiated with different functions in the species studied.

Neozygite sp. (Zygomycetes) show actin microfilaments only during the septal development. including spots. plaques and globular actin arrangement in apical and subapical regions (Butt \& Heath. 1988).

Hoch \& Staples, (1983) showed that actin structure is related to its ligation to intracellular structures as observed in Uromyces phaseoli. wherein it was possible to demonstrate that actin plaques in hyphae perifery corresponded to actin filaments attached to filassomes by using light microscopy and «freeze-fracture».

The association between actin and cell wall is related to sites of cell wall formation and extension and suggest its involveme.t in processes of synthesis and modification of cell wall. Actin filaments are thought to be involved in 
organelles and vesicles transport (Heath, 1988; Kaminskyj et al. 1989; McKerracher \& Heàth, 1987; Gooday 1995).

The actin patches along the peripheral region of the hyphae ensure, possibly the hyphal branching which may require the formation of an actin cap in the new hyphae. The peripheral location of actin patches also suggest that they provide contacts between cell wall, plasmalemma, thus serving as anchoring sites for a meshwork of cytoskeletal elements envolved in cytoplasmic migration and contraction (Hoch \& Staples, 1983; Heath, 1987; McKerrather \& Heath, 1986; Kaminskyj \& Heath, 1996). By visual inspection it was clear that the number of actin patches and plaques varied somewhat among the species studied. The actin distribution pattern was somewhat different in organisms analized.

Mulholland et al. (1994) proposed that, in yeasts, the actin cytoskeleton present in cell under dense patchelike structures probably was involved in the wall growth and osmotic regulation.

In fungi the link between actin filaments and vesicular migration was demonstrated by using detergent treatment of cells. The treatment inhibited the migration of vesicules of subapical to apical region through the actin despolimerization (Heath, 1988).

Heath (1995) suggested the close assotiation between hyphal growth and cytoskeleton elements. The distribution of actin with that of mitrotubules in hyphal tips of filamentous fungi has lead to the assumption that microfilaments might function in the compartimentalization and transport of cytoplasmic constituents during cell growth.

Technical and manual procedures used in the preparation of samples for the fluorescent light microscopy induce a high instability in the actin microfilaments of apical region. In this way, the hyphae may be manipulated only the necessary and the mycelia may be mantained wet during the preparation (Heath. 1987, 1988; Roberson, 1992).

The use of cytochemical probes has been required for the in situ identification and localization of cytoskeleton components. The visualization of various actin forms may reflect the multiple functions of this protein and/or forms its regulation during hyphal growth.

\section{CONCLUSIONS}

This study is the first report of actin cytoskeleton in hyphal cells of Absidia cylindrospora, Gongronella butleri and Mucor javanicus, three zygomycetous fungi and revealed the actin structure, distribution and cell localization.

The light microscopic results presented in this study reveal that actin is arranged in different forms in all species studied: 1) individual plaques, patches and spots; 2) coarse fibers; 3) thin filaments and 4) amorphous cytoplasmic actin. Indeed, the actin localization varied according to the species.

The results obtained in this study are used as a basis to identify the specific actin functions in the species studied, which are under investigation. and will serve as a basis for further experimental investigations intended to clarify the function of the actin in apical growth and organelles movement necessary for tip hyphal extension in Zygomycetes fungi.

\section{ACKNOWLEDGEMENTS}

The authors are grateful to, CNPq, FINEP and PADCT for the finantial support.

\section{REFERENCES}

Anderson, J. M. \& Soil, D. R. (1986). Differences in actin localization during bud and hypha formation in the yeast Candida albicans. J. Gen. MicrobioL. 132:2035-2047

Attapattu, M.C. (1995). Acute rhinocerebrat mucormycosis caused by Rhizopus arrhizus from Sri Lanka. J. Trop. Med. Hyg. 98: 355358

Barja, F.; Nguyen, B. N. \& Turian, G. (1991). Localization of actin and characterization of its isoforms in the hyphae of Neurospora crassa. FEMS Mierobiol. Lett. 77:19-24

Bartinicki-Garcia, S. F.; Hergert, F.\& Gierz, M. (1990). A novel computer model for generating cell shape: application to fungal morphogenesis. In: Biochemistry of cell walls and membranes in fungi. Kulun, P. J.; Trinci, A P. J.; Jung, M. J.; Goodsey, M. W.; Cooping, L. G. (Eds.). Springer.Verlag, Berlin.

Bittencourt, A. L.; Araújo, M. G. S.; Paes, M. S. F. (1980). Occurrence of subcutaneous zygomicosis (Entomophtoromycosis basidiobolae) caused by Basidiobolus haptosports with pulmonary envolvement. Mycopathol. 71:155-158

Butt, T. M. \& Heath, I. B. (1988). The changing distribution of actin and nuclear behavior during the cell cycle of the mite pathogenic fungus Neozygites sp. Eur. J. Cell Biol. 46:499-505

Campos Takaki, G. M. (1984). Aspectos bioquimicos e ultraestruturais das paredes celulares de fungos da Ordem Mucorales (Zygomycetes). Tese de doutoramento. Universidade de Sao Paulo.

Certik, M.; Balteszova, L. \& Sajbirox, J. (1997). Lipid formation and $\gamma$ linolenic acid production by Mucorales fungi grown ins sunflower oil. Let1. Appl. Microbiol. 25:101-105

Dube, H. C. (1978). A textbook of fungi, bacteria and viruses. Vikas Pub. House.

Endo, A.; Takeshima, H. \& Kuwabara, K. (1985). Acetil coA carboxilase inhibitors from the fungus Gongronella butleri. J. Antib. 
Actin cytoskeleton structure - Shari'a, A. et al.
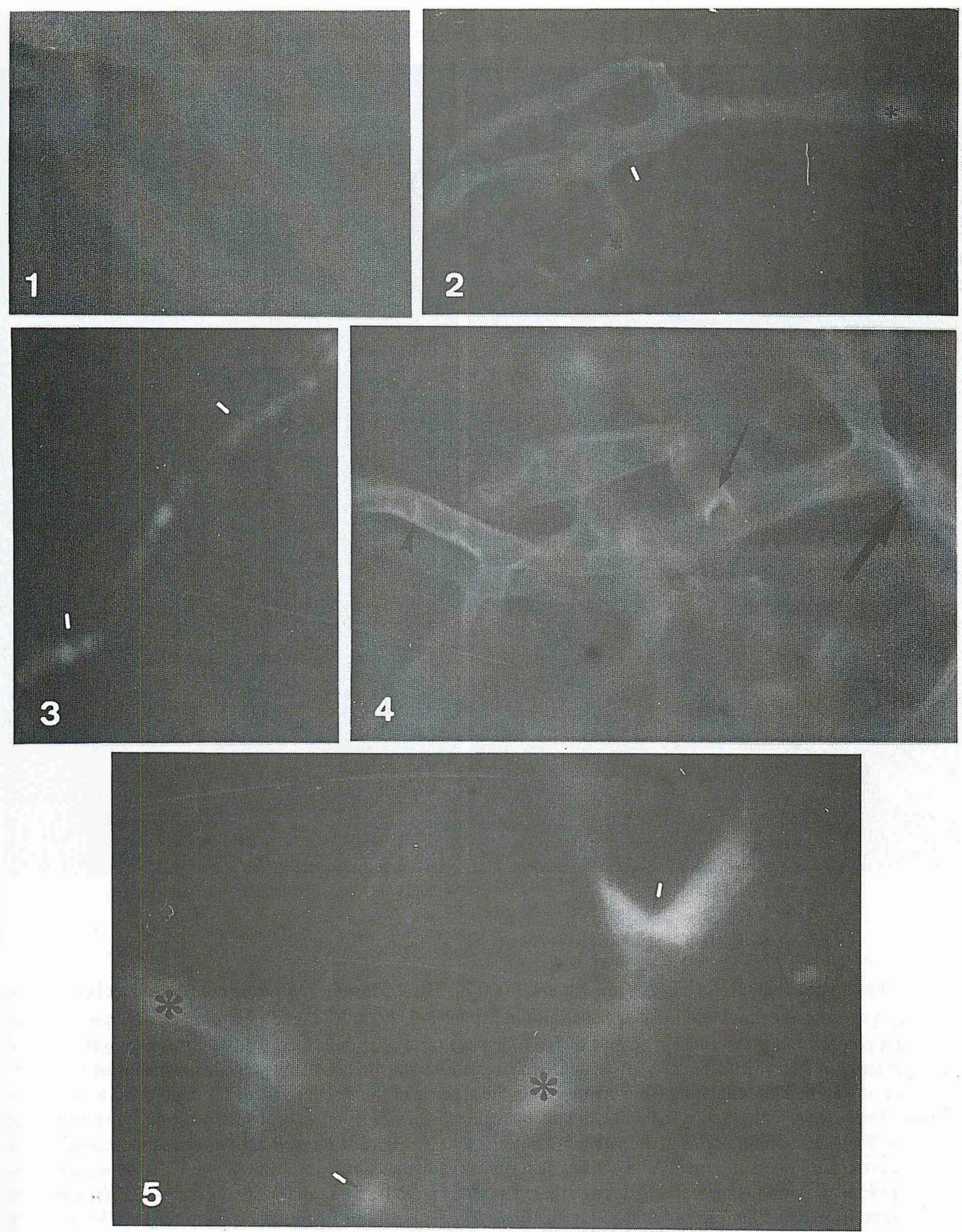

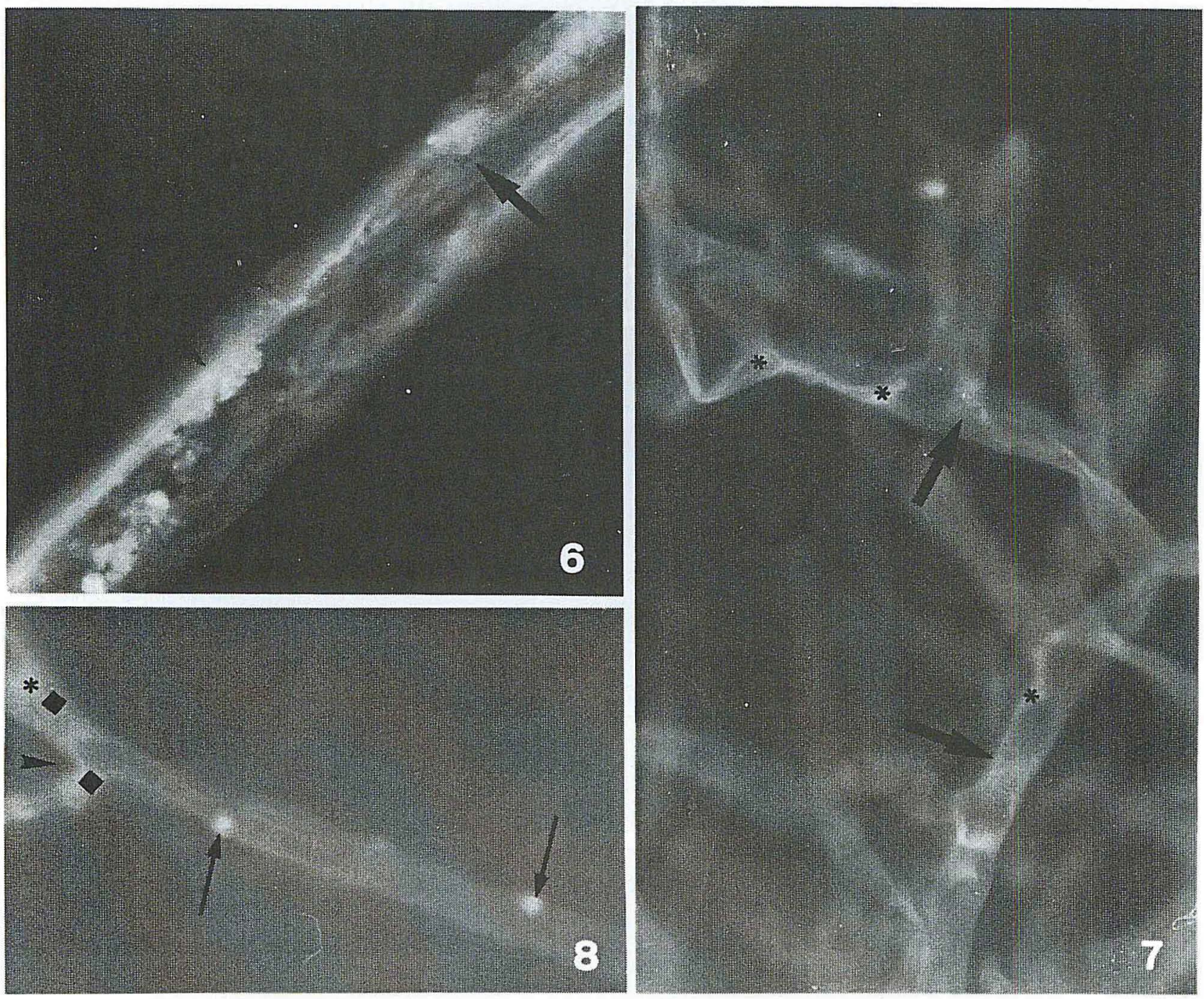

Figure 1. Fluorescence control. Gongronella butleri. 1.000 X.. Fig. 2. Absidia cylindrospora. Actin patches (*), and bands in septa region (arrow) and a amorphous form in hyphae (\$). 1.000 X. Fig. 3. Absidia cylindrospora, Bright fluorescent patches and glomerules in central region of hyphae (arrow). 1.000 X. Fig. 4. Gongronella butleri. Actin labeling in forms of fibers along the cell wall (arrow), hyphal extensions (arrow head); transversal cross-bands arrangements in septa region an hyphal branching (thin arrow). Note the absence of fluorescence in apical region. 1.000 X. Fig. 5. Gongronella butleri. Actin staining in hyphae branching region (arrowhead) and amorphous diffuse form in cytoplasmic region $\left(^{*}\right)$. Intense fluorescence as actin patches (arrow). 2.000 X. Fig. 6. Gongronella butleri. A close association between coarse actin fibers, filaments and patches at periphery of hyphae (arrows). 2.000 X. Fig. 7. Mucor javanicus. Diffuse amorphous fluorescence staining through the cytoplasmic region (arrow) and under the form of thin filaments at the hyphae periphery $\left({ }^{*}\right)$. Fluorescent 1.000 X. Fig. 8. Mucor javanicus. Bright fluorescent spots at the hyphae periphery (arrow) and thin filaments in branching region (arrowhead). Amorphous fluorescence $\left(^{*}\right.$ ) and actin patches associated to filaments ( $) .1 .000 \mathrm{X}$. 
$38: 599-6(1) 4$

Espinel-Ingroff, A.; Oakley, L. A. \& Kerkering, T. M. (1987). Opportunistic zygomycotic infections. Mycopathol. 97:33-41

Gooday, G. (1995). The dynamics of hyphal growth. Mycol. Res., 99:385-394

Heath, I. B. (1987). Preservation of a labile cortical array of actin filaments in growing hyphal tips of the fungus Saprolegnia ferax: Eur. J. Cell Biol. 44:10-16

Heath, I. B. (1988). Evidence against a direct role for cortical actin arrays in saltatory organelle motility in hyphae of the fungus Saprolegnia ferax: J. Cell Sci. 91:41-47

Heath, I. B. (1990). The roles of actin in tip growth of fungi. Int. Rev. Cytol. 123:95-127

Heath, I. B. (1995). Integration and regulation of hyphal tip growth. Can. J. Bot. (Suppl.) 73:S131-1.39

Hesseltine, C. W. \& Anderson, R. F. (1957). Microbiological production of carotenoids. I. Zygospores and carotene produced by intraespecific and interespecific crosses of Choanephoraceae in liquid media. Mycol. 49:449-452

Hitt, A.L. \& Luna, E. J. (1994). Membrane interactions with the cytoskeleton. Curr. Op. Cell Biol. 6:120-130)

Hoch, H.C. \& Staples, E. (1983). Visualization of actin in situ by rhodamine conjugated phalloin in the fungus Uromyces phaseoli. Eur. I. Cell Biol. 32:52-58

Howard, R. J. \& Raist, J. (1980). Cytoplasmic microtubules and fungal morphogenesis: ultrastruetural effects of methyl benzimidazole.2. $\gamma$ carbamate determined by freeze substitution of hyphal tip cells. J. Cell Biol. 87:55-64

Jackson, S. L. \& Heath, I. B. (1990). Evidence that actin reinforces the extensibile hyphal apex of the oomycete Saprolegnia ferax: Protoplasma. 157:144-153

Kaminskyj, S. G. W.; Yoon, K. S. \& Heath, I. B. (1989). Cytoskeletal interactions with post.mitotic migrating nuclei in the oyster mushroom fungus Pleurotus ostreatus: evidence against a force generating role for astral microtubules. J. Cell Sci. 94:663-674

Kaminskyj, S. G. W. \& Heath, I. B. (1996). Studies on Pleurotus ostreatus: evidence against a force generating role for astral microtubules. J. Cell Sci. 101:663-674

Kimura, M.; Udagawa, S.; Toyazaki, N.; Iimori, M.; Hashimoto, S. (1995). Isolation of Rhizopus microscoporum var. rhizopodiformis in the ulcer of human gastric carcinoma. J. Med. Vet. Mycol. 33:137-139

Lehrer, R. I.; Howard, D. H.; Sypher, P. S.; Edwards, E. S. J. E.; Segal, G. P.; Winston, D. J. (1980). Mucormycosis. Am. Int. Med. 93:93-108

Levy, S. A; Scmiff, K. W. \& Kaufman, L. (1986). Systemic zygomycosis diagnosed by fine needle aspiration and confirmed with enzyme immunoassay. Chest 90:146-148
McKerracher; L. J. \& Heath, I. B. (1987). Cytoplasmic migration and intracellular organelle movements during tip growth of fungai hyphae. Exp. Mycol. 11:79-100

Mitchell, S. J.; Gray, J.; Morgan, M.E.; Hocking, M.D.; Durbin, G. M. (1996). Nosocomial infection with Rhizopus microsporus in preterm infants: association with wooden tongue depressors. Lancet 17:441-443

Mulholland, J.; Preuss, D.; Moon, A ; Wong, A ; Dirubin, D.; Botstein, D. (1994). Ultrastructure of yeast actin cytoskeleton and its association with the plasma membrane. J. Cell Biol. 125: 381-391

Roberson, R.W. (1992). The actin eytoskeleton in hyphal cells of Sclerotium rolfsii. Mycol. 84:41-51

Runenberg, P. \& Raudaskoski, M. (1986). Cytoskeletal elements in the hyphae of the homobasidiomycete Schizophyllum commune visualized with indirect immunofluorescence and NBD-phallacidin. Eur. J. Cell Biol. 41:25-32

Salo, V.; Nhni, S. S.; Virtanen, I.; Raudaskoski, M. (1989). Comparative immunocytochemistry of the cytoskeleton in lilamentous fungi with dikaryotic and multinucleate hyphae. J. Cell Sci. $94: 11-24$

Schipper, M. A.; Maslen, M.M.; Hogg, G.G.; Chow, C.W.; Samson, R.A. (1996). Human infection by Rhizopus azygosporus and the oceurrence of azygopores in Zygomycetes. I. Med. Vet. Mycol. 34:199-20)3

Schliwa, M. \& Blerkom, J. (1981). Structural interaction of eytoskeletal components. J. Cell Biol. 90:222-235

Temperli, E.; Roos, U. P. \& Hohl, H. R. (1990). Actin and tubulin cytoskeleton in germlings of the oomycete fungus Phytophtora infestuns. Eur. J. Cell Biol. 53:75-88

Tombs, M. P. \& Blake, G.G. (1982). Stability and inhibition of Aspergillus and Rhizopus lipases. Biochem. Biophis. Acta. 70:8189

Trudel, J. \& Asselin, A. (1990). Detection of chitin deacetylase activity after polyacrylamide gel electrophoresis. Anal. Biochem. 189:249-253

Walsh, T.J.; Renshaw, O.; Andrews, J.; Kwon-Chung, J., Cunnion, R.C.; Pass, H.I.; Taubenberg, J.; Wilson, W.; Pizzo, P.A. (1994). Invasive zygomycosis due to Conidiobulos incongruus. Clin. Infect. Dis. 19:423-430

Weitzman, I.; Whittier, S.; Mckitrick, J. C.; Della Latta, P. (1995). Zygospores: the last word in identification of rare or atypical Zygomycetes isolated from clinical specimens. J. Clin. Microbioi. $33: 781-783$

West, B.C.; Oberle, A D. \& Kwong-Chung, K. J. (1995). Mucormycosis caused by Rhizopus microsportus var. microsporus: cellulitis in the leg of a diabetic patient cured by amputation. J. Clin. Microbic!. $33: 3341-3344$ 